\title{
A Deepened Hunger for Seriousness: 'Mr. Eliot's Sunday Morning Service’
}

\author{
Rick de Villiers \\ Department of English University of Pretoria South Africa \\ rick.devilliers@up.ac.za
}

For nearly a century the quatrain poems of T. S. Eliot, collected in Poems (1920), have occupied a comparatively peripheral space within the enterprise of Eliot studies. Despite the frequency with which some of them have been anthologized, these poems have elicited far fewer critical responses than most of Eliot's other work. The primary reason for this neglect is that the quatrain poems are largely regarded as satirical or comical meanderings that do not conform to the more 'serious' agenda of Eliot's oeuvre. 'Mr. Eliot's Sunday Morning Service' is a case in point, since it has the appearance of a learned and almost unintelligible joke. However, it is the aim of this article to demonstrate that Eliot's growing indignation with perverted spiritual practices is couched within the satire of the poem. It is further argued that the poem shows Eliot's hunger for seriousness to have grown since 'The Hippopotamus', a poem written two years prior which also deals the corruption of established religion. In this poem, Eliot's vituperation is sustained and is ultimately indicative the poet's distaste for spiritual apathy, a theme which will reach its zenith some three years later in The Waste Land.

Key words: allusion; Christ;'Mr. Eliot's Sunday Morning Service'; Origen; Poems (1920); Sweeney;

How unpleasant to meet Mr. Eliot!

With his features of clerical cut,

And his brow so grim

And his mouth so prim

And his conversation, so nicely

Restricted to What Precisely

And If and Perhaps and But.

'Five Finger Exercises', V

Around the time that T. S. Eliot described himself in terms of these humorous though deprecating lines in the mid-1930s, he was on his way to becoming a fully-fledged poet of the cloth. He began writing hagiopoetic plays and pageants, served as Church Warden of his local parish, and suffered through a self-imposed vow of celibacy. To some of his 
literary associates who had known him since the days of King Bolo and his 'big black bassturd kween' (Eliot 2009, 137), the clerically cut Mr Eliot seemed changed for the worse. (Ezra Pound, for instance, would sardonically promote his friend to 'Reverend Eliot' in Canto XLVI). But if the lines from 'Five Finger Exercises' suggest anything, it is that Eliot's sense of humour and sense of seriousness often wear similar masks.

The quatrain poems of Poems (1920) are a case in point. Though these poems have generally been regarded as an anomalous (and comparatively unsuccessful) formal experimentation in flippancy, there is a great deal of gravity beneath the rhymes. 'The Hippopotamus' and 'Mr. Eliot's Sunday Morning Service' are two quatrain poems that deal explicitly with religion. Both tar established spiritual practices with a like brush of scepticism, presenting the flesh as much too sullied or much too solid. 'The Hippopotamus' throws into relief the frailty of animal man and the seemingly unshakable foundations of the True Church. While the hippopotamus presents a picture of the ridiculous and grotesque and redeemable in humanity, it is really established religion that draws the poet's scorn: its self-assurance, simoniac practices, and miasmic stagnation all come under attack. In 'Mr. Eliot's Sunday Morning Service' similar concerns alight. The exegetical muddying of the Word is satirized through mimicry of that muddying, while corporeal existence, with its attendant humility and suffering, is subtly proffered as a means to escape intellectual perversity. But the correspondences between the two poems are not nearly as striking as the differences. Where 'The Hippopotamus' is binary, simplistic and readily comprehensible, 'Mr. Eliot's Sunday Morning Service' is fissiparous, complex and arcane. ${ }^{1}$ Its verbiage, disparate imagery and theological subtlety are couched in a stream of consciousness that leaps from thought to thought without pausing for conclusion. Admittedly, not reaching conclusion is integral to the poem's mimetic satire, but this circumspect approach shows Eliot's hunger for seriousness to have deepened since 'The Hippopotamus', which was written two years earlier.

During the latter half of the decade, Eliot supplemented his income by writing reviews of new publications in philosophy, literature and theology. His opinions on the latter reflected, contrastingly, his respect for but distance from religion. Still far from his conversion to Christianity, he would remark that 'religion, however poor our lives would be without it, is only one form of satisfaction among others, rather than the culminating satisfaction of all satisfaction' (1916b, 542-543). And yet, Eliot took exception to facile interpretations and applications in theology. He had, since childhood, rejected the codified morality of his family's Unitarianism and maintained throughout his life a marked distaste for comfortable systems of belief that showed in some way or another the mitigating meanderings of humanist thinking. Thus, in another review of 1916, for example, Eliot would criticize an author for suggesting that the 'following of Christ is "made easier" by thinking of him "as the being in whom that union of God and man after which all ethical religion is most fully accomplished"', concluding that '[c]ertain saints found the following of Christ very hard, but modern methods have facilitated everything' (1916a, 112). 
Nowhere is Eliot's demand for seriousness and hardship in spiritual matters more evident than in his poetry. His juvenilia dealing with saints have in common an arduous and unrelenting fleshly suffering, while the mature reflections of his Christian masterpiece, Four Quartets, are founded upon the lonely and stringent demands of the via negativa. 'The Hippopotamus', however, is perhaps the poem in which religious severity is in shortest supply. As I argue elsewhere (De Villiers, 2011, 71), the bathos of the concluding three stanzas undercuts the seriousness promised at the outset of the poem. The speaker - aloof, witty, and provocative for the sake of provocation - seems above offering a personal stance. However, two years later Eliot felt the need to revisit the subject matter with greater self-consistency and self-investment, offering Mr Eliot's take on a certain Sabbath's proceedings.

Yet the question of the speaker is not a simple matter. The title of the poem hints at dramatic monologue, though no clear picture of the persona can be developed. He is there and not there, felt but unseen. At best we can glean that he is a lay preacher and that, since this is a Sunday service, he probably does not belong to a congregation of Seventh Day Adventists. There is not even enough detail to declare absolutely that the speaker in question is Thomas Stearns and not some other Eliot. Lyndall Gordon (1977, 110), for instance, ventures that the person in question might be a cousin of Eliot's who was an ordained Unitarian minister. While a possibility, it seems unlikely that any thoroughgoing member of the Unitarian church would acknowledge the Father, Son and Holy Spirit as distinctly as the speaker does in stanzas three and four. If other Eliots less famed can be knocked from the list, only our first impulse - to identify the eponymous character with the real-life figure - can be followed.

In favour of this conjecture is the choice of epigraph. Eliot, in both his poetry and criticism, found The Jew of Malta useful on more than one occasion. One example is 'Portrait of a Lady' which, like the poem in question, takes its epigraph from The Jew of Malta. The respective phrases quoted in either poem occur less than fifty lines apart in Act IV Scene 1 of the play, and a further connection is revealed by the uncustomary attribution. Eliot seldom divulges the source of an epigraph; it is a rare act in his oeuvre and utterly unique in the quatrain collection. The result, at least in the case of 'Mr. Eliot's Sunday Morning Service', is Pavlovian conditioning: the direct reference nudges the reader in the direction of Eliot's 1919 essay, 'Christopher Marlowe', in which particular attention is devoted to The Jew of Malta:

If one takes the Jew of Malta not as tragedy, or as a 'tragedy of blood', but as a farce, the concluding act becomes intelligible; and if we attend with a careful ear to the versification, we find that Marlowe develops a tone to suit his farce, and even perhaps that this tone is his most powerful and mature tone. I say farce, but with the enfeebled humour of our times the word is a misnomer, it is the farce of the old English humour, the terribly serious, even savage comic humour ... (1951, 123)

Eliot gives the reader a key to his own poem and its 'savage comic humour'. In isolation, the epigraph is droll. But read within the context of its proper source, it becomes 
satirical. Barabas and his henchman, Ithamore, open the scene (IV. 1) ridiculing the false piety of Christians. The intimation of the first few exchanges is that the nunnery in Malta is little more than a glorified brothel where 'every year [the nuns] swell' (1.6). The culprits behind the annual impregnations are the monks. Ithamore's epithet for them, 'religious caterpillars' (line 21), is not only aptly phallic but also hints at the material greed underlying established religion ('caterpillar' is an archaic term of abuse for a greedy person who preys on a community). So with its dual association of sex and money, the epigraph sets the tone for 'Mr. Eliot's Sunday Morning Service'.

Polyphiloprogenitive

The sapient sutlers of the Lord

Drift across the window-panes.

In the beginning was the Word. (lines1-4)

The monstrous opening word is an Eliot coinage. It highlights through its morphology respective aspects of both The Jew of Malta's monks, and of the learned theologians that feature in the poem. The 'caterpillars' are 'polyphiloprogenitive' in that they exhibit a love for copiously creating progeny, while the 'masters of the subtle schools' share the jaw-breaking adjective because of their penchant for proliferating and obfuscating commentaries. There is, in the word 'polyphiloprogenitive', fusion between the perversity of the flesh and the perversity of the mind: while the monks of Malta father bastard children, the 'sapient sutlers' spawn wayward beliefs.

A 'sutler' is a provisioner to an army post, an agent meant to supply means of sustenance to those going into battle. Putting aside the mercantile nature of this job, it is a task that requires directness. But the members of the congregation who daily try to fight off temptation are dependent on the roundabout ways of the clergy. In the beginning is not the Word, but rather what the learned men of the cloth present. Eliot's positioning of John 1.1 is highly ironic, since many other words, subsequent to the Word (both in the poem and in the history of theology), are now the medium to the Word.

In the second stanza, the unuttered sermon moves from the image of the 'sapient sutlers' to the more abstract recesses of the speaker's mind, where one of the most prolific exegetes in Christendom surfaces as a symbol of scholastic verbosity.

In the beginning was the Word.

Superfetation of $\boldsymbol{\tau} \dot{o} \boldsymbol{e} \boldsymbol{e} \nu$,

And at the mensual turn of time

Produced enervate Origen. (lines 5-8)

Origen (circa 185/6-254) was a third century theologian famous for his indefatigable exegeses of biblical scripture. Having written over six thousand books, he is the epitome of polyphiloprogenitive. His Commentary on the Gospel of John alone, which has bearing on 'Mr. Eliot's Sunday Morning Service', comprises 32 books and is hailed as the 'greatest exegetical work of the early church' (Heine in Origen 1989, 
3). But Eliot's allusion to the historical figure is not salutary. Origen is introduced, euphemistically, as 'enervate'. The poem draws upon the commonly held belief ${ }^{2}$ that Origen was a eunuch who had paid a doctor to castrate him so that 'his reputation and respectability as a private instructor of young men and women' may be ensured (McGuckin 2004, 6). He thus stands in opposition to three words in the second stanza, all of which carry definite biological connotations. 'Superfetation' is the 'condition in which there is fertilization of a second ovum in a woman already pregnant' (Black's Medical Dictionary, Thomson 1965, 862); 'mensual', though a neologism, has its root in menstrual; and 'produced', disregarding its more neutral applications, contrasts directly with Origen's own sterility.

The stanza opens with its focus on fecundity (John 1. 1 itself draws upon Genesis 1 , the story of creation) and abruptly ends with 'enervate Origen'. The phrase 'In the beginning was the Word' that concludes the first stanza is echoed in the second so that it may be revised and qualified, as Origen's commentary of the Gospel of John had done. Though the biblical verse seems secure behind the grammatical insulation of a full stop, the very act of repetition stirs doubt. This doubt is aggravated by the confusing and incomplete sentence that follows. Line six introduces ' $\tau \dot{\partial} \boldsymbol{\epsilon} \boldsymbol{\epsilon} \nu$ ' (to en): God, unity, or the essential being. 'Superfetation of $\boldsymbol{\tau} \dot{\partial} \mathbf{\epsilon} \boldsymbol{\epsilon} \nu$ ' cannot be said to stand in syntactical relation to the lines following, nor does the punctuation allow for a qualification of the preceding line. But if the words are taken at face value, they show greater relevance to the opening of the stanza than to any other part, and may serve as a qualification of the Word - an act that in itself revivifies one of Origen's most contentious beliefs.

Aside from his emasculated status, Origen was not shy of controversy. Having had fifteen of his doctrinal conclusions declared anathema in 553, he was a persona non grata within the Catholic Church. But his most famous heresy related the relationship between God the Father and God the Son. Edwards $(2002,2)$ explains that 'after 325, when the Nicene Council had decreed that the Father and Son were of one nature (homoousios, "consubstantial"), heresiologists convicted Origen of straying to the other extreme, and teaching that the Son was so inferior that he did not know the Father and was himself a member of the created order'. Whether the accusation was founded or not (currently there is a drive to rescue Origen from heretical stigma), line six draws the

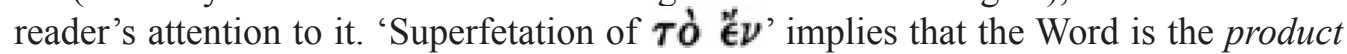
of God, and not the same as God. This is consistent with Origen's interpretation of John 1. 1: 'But someone will say with good reason that the God of all things is clearly a beginning too, proposing that the Father is the beginning of the son, and the creator is the beginning of the things created and, in general, God is the beginning of the things which exist ...' $(1989,54)$. And: 'Since the firstborn of all creation is the image of the invisible God, the Father is his beginning. And likewise also Christ is the beginning of those made according to the image of God' $(1989,55)$.

Origen is not only enervated himself, but enervates the Word. The verbosity of the first two stanzas is a satirical reflection of Origen's methods - erudition that 
does not lead to clarity but confusion, supplementation that waters down that which it supplements. His prodigious commentary further undermines the unity that is implicit in $\boldsymbol{\tau} \dot{\partial} \boldsymbol{~} \boldsymbol{\epsilon}^{\prime} \boldsymbol{\nu}$, disseminating the Word among words and splintering the Trinity. But the opening of the poem seems to dismiss Origen's self-righteous question, 'For how can teaching accomplish anything without a multitude of words . . . ?' $(1989,162)$, exactly by mimicking the exegete's long-windedness, and causing overwhelming bewilderment for the reader.

In the next two stanzas some respite is given.
A painter of the Umbrian school
Designed upon a gesso ground
The nimbus of the Baptized God.
The wilderness is cracked and browned
But through the water pale and thin
Still shine the unoffending feet
And there above the painter set
The Father and the Paraclete. (lines 9-16)

What is immediately visible is the comparable freedom of these lines. With half the number of punctuation marks and double the number of enjambments of the first two stanzas, the words breathe more easily. The syntax, also, is straightforward. Furthermore, the description of an Umbrian painting homes in on a single scene rather than branching out in many directions at once. In contrast with the poem's opening, there is focus and clarity. The calm of these lines shares something with the third movement of 'Burnt Norton' where one way to escape the world and its metalled ways is to go by the way of 'abstentation from movement' (Eliot 1963, 193). Eliot's use of ekphrasis creates a still point in a poem that otherwise darts chaotically from connotation to connotation. There is a faint reminder of the waste land that awaits ('The wilderness is cracked and browned'), but the focal point is Christ's radiant and unoffending feet.

According to one critic (Watkins 1964, 73), the most likely source for this description is Piero della Francesca's 'The Baptism of Christ': 'Francesca's painting of the baptism is a gesso panel, and since 1861 it has been owned by the National Gallery, London, where Eliot must have seen it many times. Indeed, Francesca was something of a discovery for the intellectuals in the period after 1915; he influenced the Cubists and one phase of the work of Picasso'. Watkins goes on to describe the painting in some detail, but also comments on a couple of inconsistencies between the poem's painting and Francesca's. In the first instance, there is no 'nimbus' or halo in 'The Baptism of Christ'. Secondly, though the 'Paraclete' or Holy Spirit appears in the form of a dove, God the Father is not ostensibly portrayed (1964, 73-75). This is not of grave import, since even if Eliot's Umbrian painting has a real-life source the details selected for presentation are filtered through subjective experience.

The symbols that dominate these stanzas are those of water and Christ's feet. Regarding the former, the word 'nimbus', though used to signify a halo, may also 
denote a rain cloud; it is accompanied by the aqueous act of baptism and the water through which Christ's feet shine. Water not only foreshadows Sweeney's entrance, but also beckons the spiritual release in 'What the Thunder Said'. Though the 'cracked and browned's landscape is within view, it is not in focus. Rather Christ's feet, immersed in the water, are at the centre of attention.

Among Eliot's uncollected works there are two other poems that refer to feet. In 'The Love Song of St. Sebastian', the speaker - pursuing the object of his desire - will 'follow where you lead, /. . f follow where your feet are white / In the darkness toward your bed . . ' (1996, 78, lines 11-13). And 'Elegy', an excised Waste Land fragment, concludes with the thought of divine retribution: 'God, in a rolling ball of fire / Pursues by day my errant feet. / His flames of anger and desire / Approach me with consuming heat' (1971, 116, lines 21-24). If there is any connection between these images and the feet in 'Mr. Eliot's Sunday Morning Service' it arrives by contrast. In the quatrain, the 'unoffending feet' are untouched by either desire or sin. They neither present the spiritualized sadomasochism of St. Sebastian's fantasy, nor the contamination implied in 'Elegy'. Their association, apart from purity, extends to Christ's corporeal manifestation. In John 12, when Judas Iscariot objects to Mary's prodigal use of nard to wash Jesus' feet, arguing that it could have been used to serve the poor, Jesus responds by saying: 'You will always have the poor among you, but you will not always have me'. On the one hand the concreteness of the image of Christ's feet offsets the abstract theo-philosophy of Origen. On the other hand, the representation is a bitter reminder that Christ is no longer here, which is why the speaker's thoughts can only be held by the portrait for an instant before plunging back into a world where the Word is not the beginning.

The poem now turns from the element of water to the element of fire, and the speaker's attention centres again on the church scene.

The sable presbyters approach

The avenue of penitence;

The young are red and pustular

Clutching piaculative pence.

Under the penitential gates

Sustained by staring Seraphim

Where the souls of the devout

Burn invisible and dim. (lines 17-24)

The derisive tone established by the epigraph is sustained in the fifth stanza's description of the clergy. The phrase 'sable presbyters' subtly attacks sanctimony, and the description of the younger presbyters, crimson and pimply, is openly unflattering. Indeed, following one sense of 'sable', their black vestments may suggest that they belong to the same sullen fraternity as Blake's 'Priests in black gowns' who, in 'The Garden of Love', represent oppressive religiosity (Ferguson et al. 1996, line 11). What is most contemptible about these figures is not their appearance, but their actions. Nearing the 
'avenue of penitence', they seek absolution by means of 'piaculative pence'. As in 'The Hippopotamus', the poet not only threads the issue of simony but also perpetuates a similar distaste for tepidity. Stanza six is an incomplete sentence rendering an incomplete picture of true penance. The 'sable presbyters' obtain their spiritual pardon by going 'Under the penitential gates' instead of 'through' them, as the original draft had it (see Eliot 1996, 377, lines 21-24). Though the seraphim represent purgation by fire, this process is somehow circumvented by the oblivious churchmen.

The concluding line of the stanza, directly borrowed from Henry Vaughan's poem, 'The Night', ironically reflects the humility of true devotion. In his poem, Vaughan draws on the story of Nicodemus who visits Christ during the night and is told that 'no one can enter the kingdom of God unless he is born of water and the Spirit' (John 3. 5). The import of the final stanza of that poem, from which Eliot takes his line, is comparable to the sentiment in Cowper's 'Light Shining out of Darkness', which is alluded to in 'The Hippopotamus': 'God works in a mysterious way . ..' (Eliot 1963, 52, line 23); Vaughan's poem, too, ponders the mysterious ways of God:

There is in God (some say)

A deep, but dazzling darkness; as men here

Say it is late and dusky, because they

See not all clear;

O for that night! where I in him

Might live invisible and dim. (in Ferguson et al. 1996, 455, lines 49-54)

What the speaker here desires is an unostentatious life of worship and commitment. He is the antithesis of the polyphiloprogenitive theologians whose learning and dedication are, in the vulgar sense of the word, pharisaic. They are 'sable' - gloomy and despairing - as they walk down the aisle, making a show of whatever burden they might carry. But the 'souls of the devout' suffer through the refining fire silently and unseen.

Another reference within stanza seven, more deeply embedded, may be to Dante's Purgatory. In Canto IX, as Dante approaches the gate of Purgatory, he is met by an angel whose face is 'so radiant, I could not bear it' $(1995,256$, line 81$)$. The angel is depicted holding a resplendent sword, but his robe is the colour of ashes. Whether or not he is a seraph is not specified, but he shares certain traits with Eliot's 'staring Seraphim'. Respectively, these custodians 'sustain' the Purgatorial entrance. In 'Mr. Eliot's Sunday Morning Service', the word 'sustain' may suggest both supporting the gates physically, and upholding their legitimacy. One possibility, as Headings $(1982,57)$ suggests, is that the seraphs are an 'architectural feature of the literal church building envisioned'. Alternatively, they are blazing guardians who keep those who are neither hot nor cold from entering purgatory. Eliot's change of 'live', as it stands in Vaughan's poem, for 'burn' implies that the expiation of sin requires a baptism of fire: 'suffering,' as Eliot puts it in his essay on Baudelaire, 'implies the possibility of a positive state of beatitude' (1951, 423). The stanza's reliance on images of arduous but true purgation underscores 
the sentiment, since Eliot, like Baudelaire, 'perceived that what really matters is Sin and Redemption' (Eliot 1951, 427).

The speaker's solemn reflections in stanza six lead to an ambivalent consideration of the natural and spiritual world.

Along the garden-wall the bees

With hairy bellies pass between

The staminate and pistillate,

Blest office of the epicene. (lines 25-28)

On a literal level, the penultimate stanza presents a description of bees moving between flowers and pollinating them. The bees are 'epicene' because they are sexless, and serve as the go-between for the male (stamen) and female (pistil) organs of the flowers. Metaphorically, the signification is multifarious. An obvious correspondence lies between the bees and Origen, and if Origen is an intermediary he must, in his capacity as teacher-theologian, pass between Christ and His bride, the church. But as Headings $(1982,57)$ argues, 'epicene' may also refer to the Umbrian painter, the presbyters or even Mr. Eliot's sermon, since they are 'all engaged in the work of pollination, passing between what Mr. Smith calls "the stamen of the Logos and the pistil of humanity". If so many agents - so diverse in their nature and purpose - stand between the Word and the world, they are possibly more of a barrier than a medium. In nature, the act of pollination is an involuntary by-product of the bees' nectar gathering. It is unconscious but natural; the 'hairy bellies' are an evolutionary mechanism to enhance the bees' capacity for pollen transfer. But in the spiritual world, all the other mediators are actively and deliberately involved in bridging the gap between God and man, often without the necessary equipment for the 'Blest office'.

With the opposition between the natural and unnatural set up, Sweeney arrives.

Sweeney shifts from ham to ham

Stirring the water in his bath.

The masters of the subtle schools

Are controversial, polymath. (lines 29-32)

His appearance in a poem about a Sunday morning service is unexpected. The disreputable houses of Mrs. Porter and Mrs. Turner are more typically his scene, getting dirty more typically his style. And yet the speaker's mind has turned from the arid abstractions of theology to the corporeal sinner and his proximity to the water of life. The oscillating and ambivalent nature of the poem asks us to look beyond the literal and the mundane to see natural man nearing the kingdom of God; the wider relevance of the allusion to 'The Night' and its biblical background shines through as Sweeney now gestures at a birth by water (John 3. 5). But in Eliot's work, (re)birth and water are two symbols intimately connected with pain and suffering. The inhabitants of The Waste Land, for instance, prefer not to face the violent awakening of spring, contentedly 
tending the flowers of evil, boredom and sterility. Yet the purgatorial potency of water must be felt if rebirth is to ensue: Phlebas's bones have already been picked clean by the currents of the sea; Sweeney's hams are still intact. Though they do not come near to Christ's 'inoffensive' feet, their physical facticity is the very condition of humility, suffering and consequent grace.

As in 'The Hippopotamus', Eliot creates tension between the fallible being and the superior institution (or its architects). Sweeney, like the hippopotamus, is grotesque and laughable. Bergson $(1911,51)$ claims that 'any incident is comic that calls our attention to the physical in a person, when it is the moral side that is concerned'. But rather than serve a corrective function, the comical enables humility through humiliation. Origen, on the other hand, is akin to the Bergsonian tragic hero - he who does not eat, sit, sleep or is even vulnerable to sins of the flesh. His castration was an apparent sacrifice in order to move closer to God, and yet it seems at odds with the Pauline imperative to endure the fragility of the flesh and carry Christ's death corporeally (II Corinthians 4. 10). The masters of the subtle schools have retreated from the turning world, not to stillness but stagnation. Ironically enough, Sweeney is the counterpoint to sterile religious abstractions. He represents simplicity, they complexity; he, nakedly animal, belongs to the physical world; they, divided amongst themselves ('schools' and not 'school') and cloaked in controversy, dwell in the intellect.

Sweeney's flesh and blood is even an antidote against Eliot's own poetic superfetation. For although he is critical of polyphiloprogenitive exegeses, his poem is dependent on their existence. There is an almost Derridean swirl of affirmation and negation: Origen, in adding to the Word, detracts from the Word; Eliot, in his turn, mounts an attack from the foundation he wishes to discredit. The poem's mockingbird satire, its derisive mimicry, its erudite swipes, lack an enabling humility. But instead of petering out in this vein, and instead of repeating the indeterminate flippancy of 'The Hippopotamus', Eliot undercuts his own loftiness through the corporeality of the incarnate Christ and the sinner in the bathtub.

\section{Notes}

1 Elsewhere (De Villiers 2011, 62-74) I discuss 'The Hippopotamus' in greater depth.

2 Recent scholarship has suggested that Eusebius, Origen's earliest biographer, falsely portrays Origen as a eunuch (McGuckin $(2004,6)$. But clearly, for Eliot, Origen's status as a eunuch is an integral part of the poem's sexual punning.

3 Eliot recalls this phrase in 'Lines to a Yorkshire Terrier': 'Little dog was safe and warm / ... Yet the field was cracked and brown / And the tree was cramped and dry. / Pollicle dogs and cats all must / Jellicle cats and dogs all must / Like undertakers, come to dust' (1963, 149 , lines $6,8-12)$. 


\section{References}

Bergson, H. 1911. Laughter: An Essay on the Meaning of the Comic. trans. C. Brereton and F. Rothwell. New York: Macmillan.

Dante. [circa 1321] 1995. The Divine Comedy. Trans. A. Mandelbaum. New York: Knopf.

De Villiers, R. 2011. A Hunger for Seriousness? T.S. Eliot's The Hippopotamus'. English Academy Review. 28 (2): 62-74.

Edwards, M. J. 2002. Origen against Plato. Aldershot: Ashgate.

Eliot, T. S. 1916a. Review of Conscience and Christ: Six Lectures on Christian Ethics. International Journal of Ethics, 27 (1): 112-113.

. 1916b. Review of Mens Creatrix. International Journal of Ethics, 27 (4): 542-543.

1951. Selected Essays. London: Faber and Faber.

. 1963. Collected Poems, 1909-1962. London: Faber and Faber.

. 1971. The Waste Land: A Facsimile and Transcript of the Original Drafts Including the Annotations of Ezra Pound. ed. V. Eliot. London: Faber and Faber.

. 1996. Inventions of the March Hare: Poems 1909-1917. ed. C. Ricks, C. London: Harcourt Brace and Company.

. 2009. The Letters of T. S. Eliot, Vol. 1 (1898-1922, Revised Edition). ed. V. Eliot, V. and H. Haughton. London: Faber and Faber.

Ferguson, M., M. J. Salter and J. Stallworthy, eds. 1996. The Norton Anthology of Poetry, 4th Edition. New York: Norton.

Gordon, L. 1977. Eliot's Early Years. New York: Oxford University Press.

Headings, P. R. 1982. T.S. Eliot, Revised Edition. Boston: Twayne.

Marlowe, C. 1969. The Complete Plays. ed. J. B. Steane. London: Penguin.

McGuckin, J. A., ed.. 2004. The Westminster Handbook to Origen. London: Westminster John Knox.

Origen. [circa 226] 1989. Commentary on the Gospel According to John. Books 1-10. In The Fathers of the Church: Origen. R. E. Heine. Washington: Catholic University of America Press.

Thomson, W. A. R. 1965. Black's Medical Dictionary. London: Adam and Charles Black.

Watkins, F. C. 1964. T.S. Eliot's Painter of the Umbrian School. American Literature, 36 (1): $72-75$. 